\title{
Asset Fixity and Backward-Bending Investment Demand Functions
}

\author{
Jaclyn D. Kropp \\ Assistant Professor \\ Dept. of Food \& Resource Economics \\ University of Florida \\ McCarty A 1157, PO Box 110240 \\ Gainesville, FL (USA) 32611-0240 \\ +1-352-294-7631 \\ jkropp@ufl.edu
}
Gabriel J. Power
Associate Professor
Dept. of Finance, Insurance \& Real Estate
School of Business Administration
Laval University (Université Laval)
2325 Rue de la Terrasse
Quebec City, QC (Canada) G1V 0A6
+1-418-656-2131 \#4619
gabriel.power@fsa.ulaval.ca




\title{
Asset Fixity and Backward-Bending
}

\section{Investment Demand Functions}

\begin{abstract}
We investigate irreversible investment behavior under uncertainty of payoffs using U.S. firm-level panel data. Specifically, we estimate the relationship between the firm's investment to capital ratio and the interest rate, while controlling for investment opportunities, real option values, uncertainty, and profitability. The results indicate that the investment demand curve is a backward-bending function of the interest rate. That is, at low interest rates an increase in the interest rate leads to additional investment by increasing the cost of postponing investment. Interestingly, the backward-bending shape of investment demand does not hold for the sub-sample of agribusiness firms in our dataset, which are characterized by greater asset fixity. Lastly, firm investment behavior is consistent with the existence of real option values.
\end{abstract}

Keywords: investment demand, irreversible investment, real options, asset fixity, interest rate JEL classification: D81, D92, Q13

Acknowledgements: The authors wish to thank Calum Turvey, Andrew Toole, and participants at the AAEA (Denver) and IFM2 Mathematical Finance meetings (Montreal). Any errors are our own. This work is/was supported by SSHRC, FQRSC, IFM2, and the USDA National Institute of Food and Agriculture, Multistate Research Coordination, Southern Region Accession No. 1006135. 


\section{Introduction and Motivation}

The neoclassical economic theory of investment states that firms invest less when interest rates are higher (Jorgensen, 1963). When investments are irreversible and payoffs are stochastic, however, the investment demand curve can be backward-bending (Chetty, 2007). In Chetty's model, firms can delay investment to learn more about its potential profitability. This result is closely related to the literature on real options in investment projects (Dixit and Pindyck, 1994). Indeed, when uncertainty is high, real option values associated with irreversible investments increase substantially (Bloom, Bond and van Reenen, 2007). As a result, in uncertain times firms are likely to either exercise growth options and invest immediately to establish market share, or postpone investing in positive net present value projects until some of the uncertainty is resolved, thus corresponding to an option to wait.

This paper builds on Chetty (2007) by empirically testing for the existence of a backwardbending investment function in terms of the interest rate, using a large panel of U.S. firms. Although the empirical literature on this specific topic is small, a notable and closely related study by Jovanovic and Rousseau (2004) found that in the context of Initial Public Offerings (IPOs), interest rates and investment are non-monotonically related. Their evidence suggests that IPOs are delayed when interest rates are low. On the other hand, the authors also found that the investment demand function of established (incumbent) firms decreases monotonically in the interest rate.

Our main analysis relies on a large panel of U.S. firms. However, another key issue affecting the investment demand function is asset fixity. To investigate the impact of asset fixity, we consider additionally a subsample of firms in the agribusiness sector. Indeed, firms in this sector have been found to be characterized by greater asset fixity (e.g., Chambers and Vasavada, 1983). If the degree of asset fixity is higher for the agribusiness sector, then we would expect such firms to exhibit investment behavior that differs from other sectors. Therefore, agribusiness firms are likely to exhibit investment behavior which differs from other sectors. 
The remainder of this paper is as follows. Section 2 introduces the theoretical model based on Chetty (2007) and real options theory. The empirical model, data, econometric specifications, estimation methodology and estimation results are presented in section 3. Section 4 concludes.

\section{Theoretical Model}

Neoclassical theory predicts that when interest rates rise, firms invest less because their cost of capital increases (Jorgensen 1963). In a recent paper, however, Chetty (2007) shows that the investment demand function is a backward-bending function of the interest rate. His analysis uses arguments similar to those from the real options literature. In his motivating example, a firm that is considering making a new investment has two choices: invest now, or wait and obtain more information. When interest rates rise, so does the cost of capital, therefore investment is less desirable. However, higher interest rates also imply higher costs of the firm's outstanding debt. This effect encourages the firm to invest in order to obtain profits sooner and thus pay off their debt more quickly.

The result of the opposing effects is a backward-bending investment demand curve as a function of the interest rate. Ceteris paribus, investment demand $I D$ is therefore increasing in $r$ for $r \in\left(0, r^{*}\right)$ and decreasing in $r$ for $r>r^{*}$ where $r^{*}$ is the interest rate at which investment demand is maximized.

More generally, the investment demand function ID for firm $i$ at time $t$ is a function of the interest rate faced by firm $i$ at time $t$ as well as other variables:

$$
I D_{i t}=f\left(r_{i t}, \mathbf{X}_{i t}\right)
$$

Note that according to neoclassical theory, $f_{r} \leq 0, f_{r r} \geq 0$, but in Chetty's model $f_{r} \geq 0, f_{r r} \leq 0$. To evaluate Chetty's claims, we test for the sign of these derivatives.

To our knowledge, the implications of Chetty's model have not been empirically tested using firm data. 


\subsection{Real Options Theory}

Real options theory helps explain investment behavior in the presence of uncertainty, particularly when a firm's investment behavior appears to be at odds with practice of investing if the net present value of the project is positive. The real options paradigm suggests that in uncertain times firms are likely to either exercise growth options and invest immediately to establish market share, or postpone investing in positive net present value projects until some of the uncertainty is resolved, thus corresponding to an option to wait.

Taken together, the two real options propositions and the expected utility hypothesis collectively lead to three testable hypotheses:

(1) If the level of capital investment exhibits a negative relationship with uncertainty and positive relationship with cash flow, then this is consistent with the expected utility hypothesis;

(2) If the level of capital investment exhibits a negative relationship with uncertainty regardless of the relationship between the level of capital investment and cash flow, then this would be consistent with an option to wait;

(3) If the level of capital investment exhibits a positive relationship with uncertainty regardless of the relationship between the level of capital investment and cash flow, then this would be consistent with firms taking advantage of growth options.

The only conflict occurs with (1) and (2) when cash flows are positive. If there is a negative relationship between uncertainty and investment and a positive relationship between cash flows and investment, then an ambiguity would arise that would not permit a distinction between a reduction in investment due the real options framework, specifically the option to wait, or risk aversion under the expected utility hypothesis. Hence, to test the three hypotheses we allow the investment demand function, $I D_{i t}=f\left(r_{i t}, \mathbf{X}_{i t}\right)$, for firm $i$ at time $t$ to be a function of cash flow and uncertainty. 


\section{Empirical Analysis}

We test the hypothesis that the investment demand curve is a backward-bending function of the interest rate when investments are irreversible and payoffs are stochastic. To test this relationship we use a firmlevel fixed effects model to estimate the relationship between the investment rate and the interest rate while controlling for investment opportunities, uncertainty, and other factors influencing investment. Furthermore, we investigate the relationships between investment and uncertainty and investment and profitability or cash flows to determine if firms make decisions based on expected utility theory or the real options paradigm.

\subsection{Empirical Model}

The econometric model considers the investment rate as a function of the cost of capital (proxy for interest rate) as well as firm- and sector-specific variables, including a proxy for real option value.

The dependent variable, annual firm-level investment rate, is constructed using operating capital. Operating capital consists of working capital, plant and equipment, goodwill, and other operating assets, financed through either debt or equity. Operating capital, $\mathrm{K}$, is the amount of investment employed in operations. The difference between operating capital at time $t$ and operating capital at time $t-1$ is used as a proxy for the invested capital in year $\mathrm{t}, \mathrm{K}_{\mathrm{t}}-\mathrm{K}_{\mathrm{t}-\mathrm{l}}=\mathrm{I}_{\mathrm{t}}$. The annual firm-level investment rate, defined as the change in invested operating capital divided by the initial operating capital stock, $\operatorname{INVESTRATE}_{\mathrm{t}}=$ $\left(\mathrm{K}_{\mathrm{t}}-\mathrm{K}_{\mathrm{t}-1}\right) / \mathrm{K}_{\mathrm{t}-1}=\mathrm{I}_{\mathrm{t}} / \mathrm{K}_{\mathrm{t}-1}$, normalizes investment by firm size. Therefore, the annual investment rate is the percentage change in operating capital from time t-1 to time $t$.

Since we are primarily interested in the relationship between the investment rate and the interest rate, the firm's cost of capital, COC, is included in the model as an explanatory variable and serves as a proxy for the firm's interest rate. Cost of capital squared is also included to allow for the hypothesized backward-bending structure of the investment demand curve. 
Several other explanatory variables are included in the model. The firm's investment rate lagged one period INVESTRATE $_{\mathrm{t}-1}$ is included to control for persistence in the dependent variable, since the rate of investment in time t-1 is likely to influence the rate of investment in the following period. Furthermore, to estimate the true relationship between a firm's investment rate and interest rates we control for the firm's investment opportunities. Thus, a proxy for Tobin's q is constructed using the ratio of market value (MV) to accumulated operating capital, $\mathrm{TOBINQ}_{\mathrm{t}}=\mathrm{MV}_{\mathrm{t}-1} / \mathrm{K}_{\mathrm{t}-1}$. Tobin's q provides a measure of how external players, specifically potential investors and creditors, view the firm's investment opportunities. Furthermore, an internal measure of investment opportunities is included in the model. This measure is the ratio of Future Growth Value (FGV) to accumulated operating capital, $\mathrm{GROWTH}_{\mathrm{t}}=\mathrm{FGV}_{\mathrm{t}} / \mathrm{K}_{\mathrm{t}-1}$, where FGV is the difference between the firm's Market Value Added (MVA) and the capitalized current level of Economic Value Added (EVA). FGV is high only when EVA can be expected to rapidly increase. The squares of the external (TOBINQSQ) and internal (GROWTHSQ) measures of investment opportunities are also included to allow for non-linear relationships.

Prior studies conclude that the explanatory power of Tobin's q with respect to the investment rate is low and find that sales and cash flow are better predictors (e.g. Abel and Eberly 2002; Gomes 2001; Erickson and Whited 2000). In an effort to incorporate these findings and the elements of real option theory discussed in the prior section, we also include measures of cash flow and uncertainty in the model. Net Operating Profits After-Tax (NOPAT) is used as a proxy for cash flow and firm profitability. NOPAT is operating income, which has been cleansed of the results of financial (e.g., the financing component of operating leases) and accounting distortions. PROFIT is NOPAT divided by operating capital $(\mathrm{K})$ to normalize profitability by size, which is standard in the real options literature (i.e. Bulan, 2005; Baum, Caglayan and Talavera, 2010). Since firm-level cash flows and sales are highly correlated, we include only cash flow in our analysis to avoid multicollinearity issues. 
Measuring uncertainty is a more difficult task and there is no straightforward method to compute it. Prior empirical studies measure firm-level uncertainty as the variability of the firm's stock returns (e.g. Bulan 2005; Baum, Caglayan, Talavera 2010). In these studies, the volatility of stock returns provide a measure of total firm uncertainty which can be decomposed into firm-specific and aggregate components using market and industry betas. The annualized measure is constructed from daily stock returns. However, if stock prices follow a random walk (Brownian motion), then the same measure of long run annualized volatility is obtained regardless of whether it is measured day by day or month by month or year by year. Furthermore, if the efficient market hypothesis holds in terms of stock prices and movements, a measure of firm-level uncertainty can be constructed using the standard deviation of NOPAT.

However, measures of uncertainty constructed using past values of NOPAT are ex post estimates, while managers base investment decisions on measures of uncertainty that are forward-looking. Thus, we appeal to the rational expectations assumption and use past realized values of the standard deviation of the firm's yearly NOPAT as a general proxy for uncertainty. This creates a rational expectations error that is added to the error term and is orthogonal to the information available at the beginning of each time period.

Furthermore, managers may view future uncertainty differently. For example, some managers may view future risk in terms of recent variability in operating income, while others may take a longer term view. We cannot address this question specifically except to try a variety of specifications of uncertainty and make a determination as to whether the results are materially different in consequence and statistics. Hence, uncertainty is specified as the two-year, four-year and nine-year standard deviations of NOPAT. The analysis is repeated using each measure of uncertainty. The variance of NOPAT is also included in the model to allow for a non-linear relationship between the investment rate and uncertainty. 
The model also includes interaction terms between NOPAT and uncertainty (the standard deviation of NOPAT) (SIGPROFIT), uncertainty and Tobin's q (SIGTOBIN), and uncertainty and growth (SIGGROWTH). In addition, a time trend (T) and time trend squared (TSQ) are included to capture changes in the investment environment and technology.

Thus, the model can is summarized by the following equation:

$$
\begin{aligned}
& \text { INVESTRATE }_{t}=\beta_{1} \text { INVESTRATE }_{t-1}+\beta_{2} \text { COC }_{t}+\beta_{3} \text { COC }_{t}^{2}+\beta_{4} \text { TOBINQ }_{t-1}+\beta_{5} \text { TOBINQ }_{t-1}^{2}+\beta_{6} \text { GROWTH }_{t-1} \\
& +\beta_{7} \text { GROWTH H }_{t-1}^{2}+\beta_{8} \text { PROFIT }_{t-1}+\beta_{9} \text { SIG }_{t-1}+\beta_{10} \text { SIG }_{t-1}^{2}+\beta_{11} \text { SIG }_{t-1} \cdot \text { PROFIT }_{t-1}+\beta_{12} \text { SIG }_{t-1} \cdot \text { TOBINQ }_{t-1} \\
& +\beta_{13} \text { SIG }_{t-1} \cdot \text { GROWTH }_{t-1}+\beta_{14} t+\beta_{15} t^{2}+\varepsilon_{t}
\end{aligned}
$$

where $S I G_{t-1}$ is the standard deviation of NOPAT at time t-1 and all other variables are defined as above. It is assumed that investment decisions are made at the beginning of the year. Hence, TOBINQ, GROWTH, PROFIT, and SIG are all measured as end of the year values for t-1 and are predetermined regressors.

\subsection{Data}

The dataset employed in the analysis consist of an unbalanced panel of firms representing 23 industries from the 2004 Stern Stewart Performance Russell 3000, which is a subset of Compustat data. The dataset contains annual information on several variables of interest including net operating profit after tax, capital, cost of capital, and market value. After deleting missing values we obtained a sample that runs from 1985 to 2003 and contains 2,685 firms.

Twenty-three industries are represented in the sample: energy, materials, capital goods, commercial services and suppliers, transportation, autos and components, consumer durables and apparel, hotels, restaurants and leisure, media, retailing, food and staples retailing, food, beverage and tobacco, household and personal products, health and equipment and services, pharmaceuticals and biotechnology, banks, diversified financials, insurance, software and services, technology, hardware and equipment, semiconductors and semiconductor equipment, telecommunication services, and utilities. Additionally, to investigate the investment behavior of agribusiness firms, we aggregate the 23 industries 
into two broadly defined industries using Standardized Industrial Classification (SIC) codes. Thus, the two categories of interest are agribusiness and non-agribusiness sectors.

\subsection{Estimation Methodology}

Equation (1) is estimated allowing for firm-level fixed effects with a robust variance-covariance estimator. Given our use of realized values of volatility as a proxy for future uncertainty, an instrumental variables approach might be more appropriate to deal with the associated endogeneity issues and the rational expectations error term created by the use of this uncertainty measure. Hence, the model is also estimated using a dynamic panel approach and the results are compared. Fixed effects in the one-step difference GMM estimation are eliminated using the approach in outlined in Arellano and Bover (1995). Lagged values $\left(2^{\text {nd }}\right.$ and $3^{\text {rd }}$ lags $)$ of all right-hand side variables are used as the instruments.

To determine whether any of the explanatory variables are endogenous, and hence difference GMM estimation is necessary, we compute Hausman tests (see e.g. Cameron and Triverdi, 2005, p. 272-273). The null and alternative hypotheses are:

$$
\begin{aligned}
& H_{0}: p \lim (\hat{\theta}-\tilde{\theta})=0 \\
& H_{a}: p \lim (\hat{\theta}-\tilde{\theta}) \neq 0
\end{aligned}
$$

where $\hat{\theta}$ is the OLS estimator and $\tilde{\theta}$ is the difference GMM estimator. The test statistic is:

$$
H=\frac{(\hat{\theta}-\tilde{\theta})^{2}}{\hat{s}^{2}-\tilde{s}^{2}}
$$

which is distributed $\chi^{2}(1)$ and where $\hat{s}$ and $\tilde{s}$ the OLS and one-step difference GMM reported standard errors of the parameter estimate, respectively.

Furthermore, we are interested in how investment behavior differs across industries due to differences in irreversibility and asset-fixity. Specifically, a Chow (1960) test is used to determine if 
agribusiness firms behave significantly different than firms in other industries. Since the dataset includes non-agribusiness firms such as banks, bio-technology firms and information technology firms, we estimate the model for both agribusiness and non-agribusiness firms. Then, we compare the investment demand curves of agribusiness firms to other firms in other sectors using a Chow test.

\subsection{Estimation Results}

Using the data described above, we estimate the investment demand function in terms of the interest rate, adjusting for uncertainty, cash flow, investment opportunities and real option values. We proceed first by discussing the descriptive statistics and the correlations between the variables and then the estimation of regression equations.

\section{( Table 1 about here )}

Examination of the descriptive statistics in Table 1 shows that the mean of annual firm-level investment is $\$ 264,310$ for the sample of firms. The standard deviation of annual firm-level investment is $\$ 2,725,880$, indicating that the firms in the sample are not homogenous and that annual firm-level investment varies widely across years and firms. Similarly, the investment rate has a mean of 0.22 and a standard deviation of 2.60. Furthermore, all of the independent variables have relatively large standard deviations except for cost of capital, which has a standard deviation of 2.1 percent. On average, firms in the sample had a cost of capital of 9 percent.

\section{( Table 2 about here )}

Correlations reveal weak relationships between the annual firm-level investment rate and the explanatory variables, as shown in Table 2. Specifically, a higher cost of capital tends to be weakly positively correlated with investment rate with a Pearson correlation coefficient of 0.0336 . Higher levels of profitability also tend to be weakly negatively correlated with the annual investments rate. Furthermore, we find a positive, but weak, association between the investment rate and standard 
deviation of profitability. Collectively, however, the correlations do not suggest as strong a behavioral response as might be expected from mean-variance analysis or expected utility hypothesis.

\section{( Table 3 about here )}

Regression results for Equation (1) estimated using a firm-level fixed effects model with a robust variance-covariance estimator are reported in Table 3. The effects of all of the variables included in the model are significant except for the effects of cost of capital squared and the time trend squared. There is a significant negative relationship between the annual investment rate and the annual investment rate lagged one period, indicating that periods of high levels of investment tend to be followed by periods of lower levels of investment.

There is a positive significant relationship between annual firm-level investment and the cost of capital. Furthermore, there is a negative, but not significant, relationship between the dependent variable and the square of cost of capital. Together these two results indicate that the investment demand curve might be backward bending. The turning point is 2.04 percent at which point the function is no longer monotonic and begins to bend backward. Therefore, at very low interest rates the investment demand curve exhibits a positive relationship between the annual investment rate and the interest rate, but once the interest rate exceeds approximately 2 percent the relationship between the annual investment rate and the interest rate becomes negative. While conventional neoclassical economic theory suggests that firms invest less when interest rates are higher, the results indicate that this is only true for some range of interest rates.

To better understand how the cost of capital, our proxy for interest rates, affects the firm-level annual investment rate, the marginal effect is calculated using Equation (2).

$$
f_{r}=\frac{\partial I N V E S T R A T E_{t}}{\partial \operatorname{COC}_{t}}=\beta_{2}+2 \beta_{3} C O C_{t}
$$

The marginal effect of the cost of capital on the annual firm-level investment rate evaluated at the mean is 17.92 , which suggests that a 1 percent increase in the interest rate increases the investment rate by 
17.92 percent. The second derivative of investment demand function with respect to the interest rate (cost of capital) is negative (-9.1892). Therefore, we find that $f_{r} \geq 0, f_{r r} \leq 0$, which supports Chetty's theoretical findings. Moreover, we seek to determine if firms make investment decisions based on the expected utility hypothesis or if there is any evidence that firms employ the real options paradigm when making investment decisions. Thus, it is also necessary to calculate the marginal effects of profitability and uncertainty. More specifically, the expected utility hypothesis predicts that:

$$
\frac{\partial I N V E S T R A T E_{t}}{\partial S I G_{t-1}}<0 \text { and } \frac{\partial I N V E S T R A T E_{t}}{\partial \text { PROFIT }_{t-1}}>0 .
$$

The total variation of INVESTRATE $E_{t}$ with respect to $S I G_{t-1}$, in the model is equal to:

$$
\frac{\text { IINVESTRATE }_{t}}{\partial S I G_{t-1}}=\beta_{9}+2 \beta_{10} \operatorname{SIG}_{t-1}+\beta_{11} \text { PROFIT }_{t-1}+\beta_{12} \text { TOBINQ }_{t-1}+\beta_{13} \text { GROWTH }_{t-1}
$$

and the total variation of INVESTRATE ${ }_{t}$ with respect to PROFIT $_{t-1}$, in the model is equal to:

$$
\frac{\text { INVESTRATE }_{t}}{\partial \text { PROFIT }_{t-1}}=\beta_{8}+\beta_{11} S_{I-1}
$$

Evaluated at the mean, both marginal effects are significant and negative as shown in Table 4. This provides evidence of real options with firms exercising their option to wait.

$$
\text { ( Table } 4 \text { about here ) }
$$

For completeness, the marginal effects of both measures of investment opportunities (internal and external views) are also calculated and reported in Table 4. Both marginal effects are significantly positive, which indicates that firms with more investment opportunities have a higher rate of annual investment.

We also estimate the model using a one-step difference GMM estimator and compared the results to the fixed effects model. The results of the difference GMM estimation are also reported in Table 3. Using the results from Table 3, the Hausman statistic for the profit variable is 5.15, which is greater than 
the critical value of 3.84 at the $5 \%$ level of significance. Furthermore, the Hausman statistic for the lagged dependent variable is 52.57 , thus providing further evidence of endogeneity and justifying the use of the one-step difference GMM approach. The $\mathbf{J}$ statistic reported in Table 3 corresponds to the HansenSargan test statistic and indicates that the test for over-identify restriction is satisfactory. Moreover, we reject the presence of second-order autocorrelation and hence conclude that lagged endogenous variables are suitable as valid instruments.

Only five coefficients are significant at a 10 percent significance level in the difference GMM estimation. The relationships between the annual investment rate and the explanatory variables lagged annual investment rate, growth and growth squared are significant and take the same signs as in the fixed effects estimation. On the other hand, the coefficient on the interaction between uncertainty and growth remains significant but now takes the opposite sign, while the coefficient the square of the time trend is now significant. Additionally, the difference GMM estimation suggests that the turning point at which the investment demand curve is no longer monotonically increasing is much lower at 0.11 percent. The marginal effects evaluated at the means are all significantly different from zero and reported in Table 4. The marginal effects of Tobin's q and profit take opposite signs in comparison to their signs when estimated using fixed effects, while all other marginal effects have the same signs as those found by the fixed effects estimation. The marginal effects are consistent both with the expected utility hypothesis and real options, more specifically, options to wait.

\section{( Table 5 about here )}

\section{( Table 6 about here )}

A Chow test indicates that the investment behavior of firms in the agribusiness sector is significantly different than the investment behavior of firms in other sectors (with an F-statistic of 10.04 when comparing the fixed effects estimations). Tables 5 and 6 present the fixed effects and difference GMM estimation results, respectively, for agribusiness and non-agribusiness firms separately. 


\section{( Table 7 about here )}

Comparing the fixed effects estimations for the two industries it appears that the effects of profitability, uncertainty, and Tobin's q are industry dependent; not only are magnitudes of these effects industry dependent but they signs are as well. Furthermore, the marginal effects also vary by industry (marginal effects evaluated at the means are reported in Table 7. There is evidence that both sectors consider real option values when making investment decisions. However, the investment behavior of agribusiness firms is indicative of growth options (the marginal effects of profitability and uncertainty are both positive and significant), while the investment behavior of non-agribusiness firms is indicative of options to wait (the marginal effects of profitability and uncertainty are both negative and significant). Moreover, the point at which the investment demand curve bends backward is lower for agribusiness firms (0.08 percent) than for non-agribusiness firms (2.01 percent).

However, a comparison of the difference GMM estimations for the two industries indicates that industry differences are driven mainly by the effects of uncertainty. More specifically, the marginal effects indicate that agribusiness firms' investment behavior is indicative of growth options (the marginal effect of profitability is positive but not significant, as shown in Table 7), while the investment behavior of non-agribusiness firms is now consistent with the expected utility theory. Furthermore, the point at which the investment demand curve bends backward for agribusiness firms (0.08 percent) is only slightly lower than the point at which the investment demand curve bends backward is for nonagribusiness firms (0.11 percent). Differences in the marginal effects and the turning points across the two sectors are likely due to differences in irreversibility of investments and asset-fixity.

Lastly, we estimate the models specifying uncertainty in various ways to determine if the relationship between uncertainty and investment is robust to such changes in specifications. When uncertainty is specified as the two-year, four-year and nine-year standard deviation of NOPAT, we find 
no noteworthy differences in the estimation results. Hence, all results presented in this paper are obtained using the four-year standard deviation of NOPAT as a measure of uncertainty.

\section{Conclusions and implications}

Firms are expected to invest less when interest rates are higher, because the cost of capital increases. Since firms, however, need to service their outstanding debt, a higher interest rate also motivates them to invest sooner, with the goal of obtaining higher profits earlier and paying off their debt more quickly. Chetty (2007) presents a theoretical model that analyzes these two opposing forces and shows that the investment demand curve should be a backward-bending function of the interest rate (or cost of capital) when investments are irreversible and payoffs are stochastic. Thus, investment should be increasing in the interest rate $r$ until $r$ reaches the point $r^{*}$, but decreasing for $r$ greater than $r^{*}$.

To our knowledge Chetty's model and its implications have not been studied empirically. In addition to investigating this relationship for a large panel of US firms, we also examine the case of agribusiness firms because they are characterized by greater asset fixity and higher market contentration, implying that the relationship should be weaker (e.g., Jovanovic and Rousseau, 2004). This paper studies the determinants of investment demand including the rate of interest (using the cost of capital as proxy) and finds that the interest rate level at which investment demand is maximized, $r^{*}$, equals 2.04 percent for all firms (using the fixed effects estimate) but only 0.08 percent for agribusiness firms. That is, Chetty's hypothesis of a backward-bending investment demand function is confirmed for the broad sample of US firms excluding agribusiness, but is rejected for the sample of agribusiness firms.

However, the difference between the interest rates at which investment in maximized for the agribusiness sector and the non-agribusiness sector becomes substantially smaller when difference GMM estimation is used. Moreover, examination of the marginal effects indicates that the two sectors are both affected by real option values, although the impacts are industry- dependent. To explain this finding, 
further research could examine differences in capital structure, asset fixity and debt levels between firms across industry sectors. 


\section{References}

Abel, A. \& Eberly, J. (2002). Investment and q with Fixed Costs: An Empirical Analysis. Working paper, Northwestern University.

Arellano, M. \& O. Bover. (1995). Another Look at the Instrumental Variable Estimation of Component Models. Journal of Econometrics, 68, 29-51.

Baum, C., M. Caglayan, \& O. Talavera. (2010). On the Sensitivity of Firms' Investment to Cash Flow and Uncertainty. Oxford Economic Papers, 62: 286-306.

Bulan, L. T. (2005). Real Options, Irreversible Investment and Firm Uncertainty: New Evidence from U.S. Firms. Review of Financial Economics, 14, 255-279.

Bloom, N., S. Bond \& J. van Reenen. (2007). Uncertainty and Investment Dynamics. Review of Economic Studies, 74, 391-415.

Caballero, R.J., E. Engel \& J. Haltiwanger. (1995). Plant-Level Adjustment and Aggregate Investment Dynamics. Brookings Papers on Economic Activity: Macroeconomics, 1-54.

Chambers, R. G. \& U. Vasavada. (1983). Testing Asset Fixity for U.S. Agriculture. American Journal of Agricultural Economics, 65( 4), 761-769.

Chetty, R. (2007). Interest Rates, Irreversibility, and Backward-Bending Investment. Review of Economic Studies, 74, 67-91.

Chow, G. C. (1960). Tests of Equality between Sets of Coefficients in Two Linear Regressions. Econometrica, 28(3), 591-605.

Erickson, T. \& Whited, T. (2000). Measurement Error and the Relationship between Investment and q. Journal of Political Economy, 108, 1027-1057.

Gomes, J. (2001). Financing Investment. American Economic Review, 91, 1263-1285.

Jorgensen, D. (1963). Capital Theory and Investment Behavior. American Economic Review, 53(2), 247259.

Jovanovic, B. \& P.L. Rousseau (2004). Interest Rates and Initial Public Offerings. NBER working paper 10298, National Bureau of Economic Research. 
Table 1: Descriptive statistics

\begin{tabular}{lcccc}
\hline & Mean & Std Dev & Minimum & Maximum \\
\hline I (in thousands ) & $\$ 264.31$ & $\$ 2,725.88$ & $\$(79,022.92)$ & $\$ 198,475.53$ \\
INVESTRATE & 0.2208 & 2.5963 & -324.2044 & 128.1046 \\
COC & 0.0909 & 0.0210 & 0.0435 & 0.1725 \\
PROFIT & 0.0819 & 0.7357 & -81.9484 & 28.9223 \\
SIGMA & 0.0872 & 1.1633 & $6.8608 \mathrm{E}-07$ & 87.1687 \\
TOBINQ & 2.5625 & 14.8792 & -868.7163 & $1,144.9297$ \\
GROWTH & 0.0148 & 1.0089 & -12.5613 & 150.6419 \\
SIGPROFIT & -0.2475 & 46.4438 & $-6,603.9971$ & $1,684.5526$ \\
SIGTOBIN & 2.2940 & 473.5041 & $-16,296.6045$ & $66,685.3906$ \\
SIGGROWTH & 0.6429 & 86.4785 & -308.6479 & $13,131.2539$ \\
Number of Firms & 2,685 & & & \\
Number of Observations & 24,315 & & & \\
\hline
\end{tabular}

Variable names: Investment (I), investment rate (INVESTRATE), cost of capital (COC), firm profit using NOPAT divided by operating capital (PROFIT), volatility (SIGMA), Tobin's q (TOBINQ), growth opportunities $($ GROWTH), volatility $\times$ profit (SIGPROFIT), volatility $\times$ Tobin's q (SIGTOBIN), volatility $\times$ growth opportunities (SIGGROWTH). 
Table 2: Sample correlations

\begin{tabular}{|c|c|c|c|c|c|c|c|c|}
\hline & INVESTRATE & $\mathrm{COC}$ & PROFIT & SIG & TOBINQ & GROWTH & SIGPROFIT & SIGTOBIN \\
\hline INVESTRATE & 1.0000 & & & & & & & \\
\hline $\mathrm{COC}$ & 0.0336 & 1.0000 & & & & & & \\
\hline PROFIT & -0.0382 & 0.0034 & 1.0000 & & & & & \\
\hline SIG & 0.0229 & 0.0239 & -0.2210 & 1.0000 & & & & \\
\hline TOBINQ & 0.0989 & 0.0720 & 0.4154 & 0.1470 & 1.0000 & & & \\
\hline GROWTH & 0.0563 & 0.0053 & -0.0579 & 0.5392 & 0.0257 & 1.0000 & & \\
\hline SIGPROFIT & -0.0130 & 0.0015 & 0.8583 & -0.3141 & 0.2861 & -0.0681 & 1.0000 & \\
\hline SIGTOBIN & -0.0276 & 0.0024 & 0.5375 & 0.1705 & 0.6937 & -0.0296 & 0.5001 & 1.0000 \\
\hline SIGGROWTH & 0.0162 & -0.0020 & -0.0475 & 0.5546 & -0.0119 & 0.9898 & -0.0554 & -0.0442 \\
\hline
\end{tabular}

Variable names: Investment (I), investment rate (INVESTRATE), cost of capital (COC), firm profit using NOPAT divided by operating capital (PROFIT), volatility (SIGMA), Tobin's q (TOBINQ), growth opportunities $($ GROWTH), volatility $\times$ profit $($ SIGPROFIT), volatility $\times$ Tobin's q (SIGTOBIN), volatility $\times$ growth opportunities $($ SIGGROWTH). 
Table 3: Fixed Effects and Difference GMM Regression Results

\begin{tabular}{|c|c|c|}
\hline Variable & Fixed Effects & Difference GMM \\
\hline INVESTRATE $_{t-1}$ & $\begin{array}{l}-0.1205 * * * \\
(0.0098)\end{array}$ & $\begin{array}{l}-0.9188 * * * \\
(0.1105)\end{array}$ \\
\hline $\mathrm{COC}$ & $\begin{array}{l}18.7541 * * \\
(8.6265)\end{array}$ & $\begin{array}{r}231.7760 \\
(171.4320)\end{array}$ \\
\hline COCSQ & $\begin{array}{r}-4.5981 \\
(41.4173)\end{array}$ & $\begin{array}{r}-1092.4700 \\
(799.3460)\end{array}$ \\
\hline PROFIT & $\begin{array}{l}-2.4308 * * * \\
(0.0726)\end{array}$ & $\begin{array}{r}3.5710 \\
(2.6444)\end{array}$ \\
\hline SIG & $\begin{array}{l}-0.6063 * * * \\
(0.0545)\end{array}$ & $\begin{array}{r}-0.1392 \\
(0.7137)\end{array}$ \\
\hline SIGSQ & $\begin{array}{l}0.0393 * * * \\
(0.0015)\end{array}$ & $\begin{array}{r}0.0086 \\
(0.0459)\end{array}$ \\
\hline TOBINQ & $\begin{array}{l}0.0955 * * * \\
(0.0020)\end{array}$ & $\begin{array}{r}-0.0289 \\
(0.0750)\end{array}$ \\
\hline TOBINQSQ & $\begin{array}{l}1.47 \times 10^{-4} * * * \\
\left(2.83 \times 10^{-6}\right)\end{array}$ & $\begin{array}{l}-7.7 \times 10^{-5} \\
\left(5.5 \times 10^{-5}\right)\end{array}$ \\
\hline GROWTH & $\begin{array}{l}5.9555 * * * \\
(0.1270)\end{array}$ & $\begin{array}{l}13.6514 * * * \\
(4.9896)\end{array}$ \\
\hline GROWTHSQ & $\begin{array}{l}-0.1027 * * * \\
(0.0034)\end{array}$ & $\begin{array}{l}-5.9757 * * * \\
(1.2309)\end{array}$ \\
\hline SIGPROFIT & $\begin{array}{l}0.1303 * * * \\
(0.0032)\end{array}$ & $\begin{array}{r}-0.1218 \\
(0.1937)\end{array}$ \\
\hline SIGTOBIN & $\begin{array}{l}-0.0083 * * * \\
\left(1.51 \times 10^{-4}\right)\end{array}$ & $\begin{array}{r}0.0027 \\
(0.0078)\end{array}$ \\
\hline SIGGROWTH & $\begin{array}{l}0.0824 * * * \\
(0.0061)\end{array}$ & $\begin{array}{l}-4.1092 * * * \\
(0.9537)\end{array}$ \\
\hline $\mathrm{T}$ & $\begin{array}{l}0.0613 * * * \\
(0.0201)\end{array}$ & $\begin{array}{r}-0.0689 \\
(0.0494)\end{array}$ \\
\hline TSQ & $\begin{array}{r}-0.0013 \\
\left(8.16 \times 10^{-4}\right)\end{array}$ & $\begin{array}{l}0.0066 * \\
(0.0036)\end{array}$ \\
\hline Intercept & & $\begin{array}{r}-11.8499 \\
(8.8411)\end{array}$ \\
\hline Number of firms & 2,579 & 2,579 \\
\hline Number of Observations & 24,315 & 14,686 \\
\hline $\begin{array}{l}\text { J statis tic } \\
\text { J } n \text {-value }\end{array}$ & & $\begin{array}{l}0.4221 \\
0.9630\end{array}$ \\
\hline Durbin-Waston & 1.6793 & 1.8739 \\
\hline Adjusted R-squared & 0.2115 & 0.4934 \\
\hline
\end{tabular}

Variable names: investment rate (INVESTRATE), cost of capital (COC), cost of capital squared (COCSQ), firm profit using NOPAT divided by operating capital (PROFIT), volatility (SIGMA), volatility squared (SIGSQ), Tobin's q (TOBINQ), Tobin's q squared (TOBINQSQ), growth opportunities (GROWTH), growth opportunities squared (GROWTHSQ), volatility $\times$ profit $($ SIGPROFIT), volatility $\times$ Tobin's q $($ SIGTOBIN), volatility $\times$ growth opportunities $($ SIGGROWTH), time trend $($ T), time trend squared (TSQ). 
Table 4: Turning Points and Marginal Effects for All Firms

\begin{tabular}{|c|c|c|c|c|}
\hline \multirow{3}{*}{ Turning point } & \multicolumn{2}{|c|}{ Fixed Effects } & \multicolumn{2}{|c|}{ Difference GMM } \\
\hline & \multicolumn{2}{|c|}{-2.00} & \multicolumn{2}{|c|}{0.11} \\
\hline & $\begin{array}{l}\text { Marginal } \\
\text { Effect }\end{array}$ & $\begin{array}{c}\text { F- } \\
\text { Statistic }\end{array}$ & $\begin{array}{c}\text { Marginal } \\
\text { Effect }\end{array}$ & $\begin{array}{c}\text { F- } \\
\text { Statistic }\end{array}$ \\
\hline $\mathrm{COC}$ & $17.918 * * *$ & 32.02 & $33.228 * * *$ & 1978.77 \\
\hline PROFIT & $-2.537 * * *$ & 1972.44 & $3.547 * * *$ & 2417.95 \\
\hline SIG & $-0.609 * * *$ & 2515.65 & $-0.201 * * *$ & 277.66 \\
\hline TOBINQ & $0.096 * * *$ & 2703.12 & $-0.029 * * *$ & 28.62 \\
\hline GROWTH & $5.960 * * *$ & 3743.40 & $13.117 * * *$ & 1278.02 \\
\hline
\end{tabular}

Notes: Variable names: cost of capital (COC), firm profit using NOPAT divided by operating capital (PROFIT), volatility (SIGMA), Tobin's q (TOBINQ), Tobin's q squared (TOBINQSQ), growth opportunities (GROWTH). 
Table 5: Fixed Effects Regression Results for Agribusiness and Non-Agribusiness Firms

\begin{tabular}{|c|c|c|}
\hline Variable & Agribusiness & Non-Agribusiness \\
\hline INVESTRATE $_{\mathrm{t}-1}$ & $\begin{array}{l}-0.1203 * * * \\
(0.0310)\end{array}$ & $\begin{array}{l}-0.1204 * * * \\
(0.0100)\end{array}$ \\
\hline $\mathrm{COC}$ & $\begin{array}{r}18.8601 * \\
(11.7464)\end{array}$ & $\begin{array}{l}19.2405 * * \\
(9.1408)\end{array}$ \\
\hline COCSQ & $\begin{array}{r}-113.6000 \\
(72.6414)\end{array}$ & $\begin{array}{r}-4.7837 \\
(43.5765)\end{array}$ \\
\hline PROFIT & $\begin{array}{l}1.7240 * * * \\
(0.3664)\end{array}$ & $\begin{array}{l}-2.4385 * * * \\
(0.0745)\end{array}$ \\
\hline SIG & $\begin{array}{l}3.9862 * * * \\
(0.6035)\end{array}$ & $\begin{array}{l}-0.6078 * * * \\
(0.0559)\end{array}$ \\
\hline SIGSQ & $\begin{array}{l}-1.9451 \\
(1.3646)\end{array}$ & $\begin{array}{l}0.0393 * * * \\
(0.0016)\end{array}$ \\
\hline TOBINQ & $\begin{array}{l}-0.0195 \\
(0.0172)\end{array}$ & $\begin{array}{l}0.0955 * * * \\
(0.0020)\end{array}$ \\
\hline TOBINQSQ & $\begin{array}{l}0.0026 * * \\
(0.0011)\end{array}$ & $\begin{array}{l}1.47 \times 10^{-4} * * * \\
-2.91 \times 10-6\end{array}$ \\
\hline GROWTH & $\begin{array}{r}2.5505 \\
(2.8398)\end{array}$ & $\begin{array}{l}5.9562 * * * \\
(0.1302)\end{array}$ \\
\hline GROWTHSQ & $\begin{array}{r}5.2531 \\
(11.3174)\end{array}$ & $\begin{array}{l}-0.1030 * * * \\
(0.0035)\end{array}$ \\
\hline SIGPROFIT & $\begin{array}{l}-12.5192 * * * \\
(3.6992)\end{array}$ & $\begin{array}{l}0.1306 * * * \\
(0.0033)\end{array}$ \\
\hline SIGTOBIN & $\begin{array}{l}0.3380 * \\
(0.1742)\end{array}$ & $\begin{array}{l}-0.0083 * * * \\
\left(1.55 \times 10^{-4}\right)\end{array}$ \\
\hline SIGGROWTH & $\begin{array}{l}-15.0341 * \\
(9.3318)\end{array}$ & $\begin{array}{l}0.0827 * * * \\
(0.0062)\end{array}$ \\
\hline $\mathrm{T}$ & $\begin{array}{l}-0.0021 \\
(0.0143)\end{array}$ & $\begin{array}{l}0.0646 * * * \\
(0.0211)\end{array}$ \\
\hline TSQ & $\begin{array}{r}0.0003 \\
(0.0006)\end{array}$ & $\begin{array}{c}-0.0014 * \\
\left(8.59 \times 10^{-4}\right)\end{array}$ \\
\hline Number of firms & 96 & 2,483 \\
\hline Number of Observations & 1,159 & 23,156 \\
\hline Durbin-Watson Statistic & 1.9876 & 1.6794 \\
\hline Adjusted R-squared & 0.1505 & 0.2790 \\
\hline
\end{tabular}

$* \mathrm{p}<0.10, * * \mathrm{p}<0.05, * * * \mathrm{p}<0.01$. Variable names: investment rate (INVESTRATE), cost of capital (COC), cost of capital squared (COCSQ), firm profit using NOPAT divided by operating capital (PROFIT), volatility (SIGMA), volatility squared (SIGSQ), Tobin's q (TOBINQ), Tobin's q squared (TOBINQSQ), growth opportunities $($ GROWTH), growth opportunities squared (GROWTHSQ), volatility $\times$ profit (SIGPROFIT), volatility $\times$ Tobin's q $($ SIGTOBIN), volatility $\times$ growth opportunities (SIGGROWTH), time trend $(\mathrm{T})$, time trend squared (TSQ). 
Table 6: Difference GMM Regression Results for Agribusiness and Non-Agribusiness Firms

\begin{tabular}{|c|c|c|}
\hline Variable & Agribusiness & Non-Agribusiness \\
\hline INVESTRATE $_{t-1}$ & $\begin{array}{l}-0.9201 * * * \\
(0.0896)\end{array}$ & $\begin{array}{l}-0.9217 * * * \\
(0.1115)\end{array}$ \\
\hline $\mathrm{COC}$ & $\begin{array}{l}-30.9967 \\
(75.2809)\end{array}$ & $\begin{array}{r}247.0600 \\
(177.8560)\end{array}$ \\
\hline COCSQ & $\begin{array}{r}191.9700 \\
(449.5340)\end{array}$ & $\begin{array}{r}-1160.6500 \\
(825.2100)\end{array}$ \\
\hline PROFIT & $\begin{array}{r}1.0746 \\
(1.7640)\end{array}$ & $\begin{array}{r}3.5704 \\
(2.6842)\end{array}$ \\
\hline SIG & $\begin{array}{l}5.4958 * \\
(2.9916)\end{array}$ & $\begin{array}{r}-0.1188 \\
(0.7267)\end{array}$ \\
\hline SIGSQ & $\begin{array}{l}-12.9221 \\
(14.5195)\end{array}$ & $\begin{array}{r}0.0081 \\
(0.0468)\end{array}$ \\
\hline TOBINQ & $\begin{array}{r}-0.1822 \\
(0.1379)\end{array}$ & $\begin{array}{r}-0.0294 \\
(0.0762)\end{array}$ \\
\hline TOBINQSQ & $\begin{array}{l}0.0117 * * * \\
(0.0045)\end{array}$ & $\begin{array}{l}\left(8.81 \times 10^{-6}\right) \\
\left(6.65 \times 10^{-5}\right)\end{array}$ \\
\hline GROWTH & $\begin{array}{r}0.4530 \\
(5.2106)\end{array}$ & $\begin{array}{l}14.0221 * * * \\
(5.0485)\end{array}$ \\
\hline GROWTHSQ & $\begin{array}{l}-23.9994 \\
(28.0117)\end{array}$ & $\begin{array}{l}-5.9399 * * * \\
(1.2372)\end{array}$ \\
\hline SIGPROFIT & $\begin{array}{l}-10.9396 \\
(20.8462)\end{array}$ & $\begin{array}{r}-0.1223 \\
(0.1974)\end{array}$ \\
\hline SIGTOBIN & $\begin{array}{r}0.8218 \\
(1.3784)\end{array}$ & $\begin{array}{r}0.0027 \\
(0.0079)\end{array}$ \\
\hline SIGGROWTH & $\begin{array}{r}35.1230 \\
(39.9408)\end{array}$ & $\begin{array}{l}-4.1078 * * * \\
(0.9632)\end{array}$ \\
\hline $\mathrm{T}$ & $\begin{array}{r}-0.0161 \\
(0.0390)\end{array}$ & $\begin{array}{r}-0.0794 \\
(0.0531)\end{array}$ \\
\hline TSQ & $\begin{array}{r}0.0011 \\
(0.0027)\end{array}$ & $\begin{array}{l}0.0071 * \\
(0.0039)\end{array}$ \\
\hline INTERCEPT & $\begin{array}{r}1.4797 \\
(3.0156)\end{array}$ & $\begin{array}{r}12.6299 \\
(9.1986)\end{array}$ \\
\hline Number of firms & 96 & 2,483 \\
\hline Number of Observations & 788 & 13,898 \\
\hline J statistic & 1.0083 & 0.4217 \\
\hline J $p$-value & 0.4410 & 0.9630 \\
\hline Durbin-Waston & 1.5024 & 1.8650 \\
\hline Adjusted R-squared & 0.4685 & 0.4995 \\
\hline
\end{tabular}

$* \mathrm{p}<0.10, * * \mathrm{p}<0.05, * * * \mathrm{p}<0.01$. All estimates are generated by Arellano-Bover one-step difference GMM with the second through fourth lags of all right-hand side variables serving as the instruments. Variable names: investment rate (INVESTRATE), cost of capital (COC), cost of capital squared (COCSQ), firm profit using NOPAT divided by operating capital (PROFIT), volatility (SIGMA), volatility squared (SIGSQ), Tobin's q (TOBINQ), Tobin's q squared (TOBINQSQ), growth opportunities (GROWTH), growth opportunities squared (GROWTHSQ), volatility $\times$ profit $($ SIGPROFIT), volatility $\times$ Tobin's q $($ SIGTOBIN), volatility $\times$ growth opportunities (SIGGROWTH), time trend (T), time trend squared (TSQ). 
Table 7: Turning Points (in percentage points) and Marginal Effects for Agribusiness and Non-Agribusiness Firms

\begin{tabular}{|c|c|c|c|c|c|c|c|c|c|}
\hline \multirow{4}{*}{ Turning point } & \multicolumn{4}{|c|}{ Fixed Effects } & \multicolumn{5}{|c|}{ Difference GMM } \\
\hline & \multicolumn{2}{|c|}{ Agribusiness } & \multicolumn{2}{|c|}{$\begin{array}{c}\text { Non- } \\
\text { Agribusiness } \\
\end{array}$} & \multicolumn{2}{|c|}{ Agribusiness } & \multicolumn{3}{|c|}{$\begin{array}{c}\text { Non- } \\
\text { Agribusines }\end{array}$} \\
\hline & \multicolumn{2}{|c|}{0.08} & \multicolumn{2}{|c|}{2.01} & \multicolumn{2}{|c|}{0.08} & \multicolumn{3}{|c|}{0.11} \\
\hline & $\begin{array}{c}\text { Marginal } \\
\text { Effect }\end{array}$ & $\begin{array}{c}\text { F- } \\
\text { Statistic }\end{array}$ & $\begin{array}{c}\text { Marginal } \\
\text { Effect }\end{array}$ & $\begin{array}{c}\text { F- } \\
\text { Statistic }\end{array}$ & $\begin{array}{l}\text { Marginal } \\
\text { Effect }\end{array}$ & $\begin{array}{c}\text { F- } \\
\text { Statistic }\end{array}$ & $\begin{array}{r}\text { Margi } \\
\text { Effe }\end{array}$ & & $\begin{array}{c}\text { F- } \\
\text { Statistic }\end{array}$ \\
\hline $\mathrm{COC}$ & 2.063 & 2.27 & $18.363 * * *$ & 31.13 & $-2.612 * * *$ & 15.32 & 34.153 & $* * *$ & 1871.36 \\
\hline PROFIT & $1.896 * * *$ & 21.82 & $-2.548 * * *$ & 1908.56 & 1.311 & 1.98 & 3.549 & $* * *$ & 2162.26 \\
\hline SIG & $3.254 * * *$ & 24.40 & $-0.610 * * *$ & 2444.71 & $5.526 * * *$ & 14.58 & -0.184 & $* * *$ & 335.19 \\
\hline TOBINQ & $-0.002 * * *$ & 24.13 & $0.096 * * *$ & 2610.83 & $-0.117 * * *$ & 4.63 & -0.029 & $* * *$ & 22.49 \\
\hline GROWTH & $2.244 *$ & 2.61 & $5.960 * * *$ & 3615.57 & $1.132 * * *$ & 10.66 & 13.467 & $* * *$ & 1207.16 \\
\hline
\end{tabular}

$* \mathrm{p}<0.10, * * \mathrm{p}<0.05, * * * \mathrm{p}<0.01$

$\underline{\text { Note: }}$ Turning points are expressed in percentage points.

Variable names: cost of capital (COC), firm profit using NOPAT divided by operating capital (PROFIT), volatility (SIGMA), Tobin's q (TOBINQ), growth opportunities (GROWTH). 